\title{
A fast and efficient method to determine the position of alien genes in transgenic plants
}

\author{
Mahmood-ur-Rahman, S. Noreen, T. Husnain* and S. Riazuddin \\ National Centre of Excellence in Molecular Biology (CEMB), 87-West Canal Bank Road, \\ Thokar Niaz Baig, Lahore-53700, Pakistan
}

\begin{abstract}
Phenotypic variations are commonly observed in transgenic plants. Basmati rice (Oryza sativa L.) and cotton (Gossypium hirsutum), locally transformed with Bt genes, also exhibited such variations in their morphology. One possible cause of these variations might be the position of transgene on chromosome (s). An experiment was conducted to determine the position of the alien genes. It was determined by Fluorescence in situ hybridization (FISH) by hybridizing fluorescien labeled DNA probe on mitotic chromosomes of transgenic rice and cotton. An easy and simple protocol was developed as compared to available lengthy and difficult methods. The method is quick and efficient.
\end{abstract}

Keywords: Bt genes, Fluorescence in situ hybridization, transgene, DNA probe.

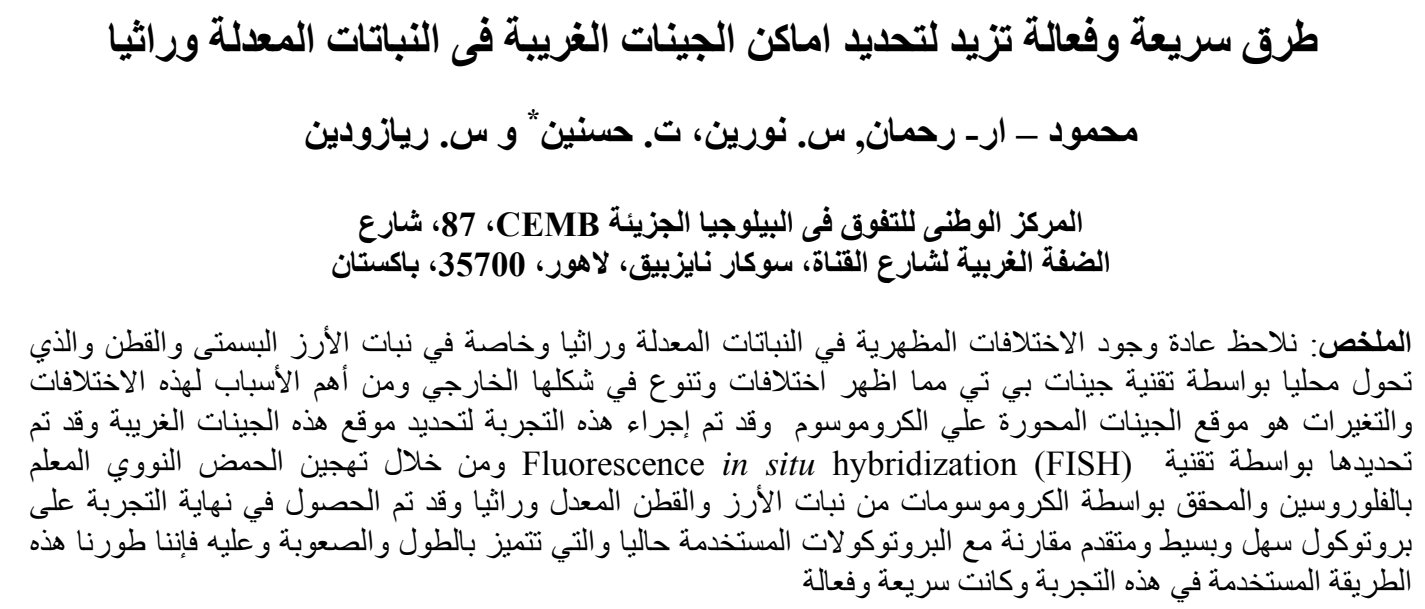

* Corresponding Author, Email: tayyabhusnain@gmail.com 


\section{Introduction}

Transgenic plants are the most urgent demand to combat with various biotic and abiotic stresses. A large number of transgenic rice plants with different kind of transgenes have been obtained (Bajaj and Mohanty, 2005). Rice and cotton were transformed with two $B t$ genes cry1Ac and cry2A (Bashir et al., 2004; Majeed et al., 2000; Riaz et al., 2006; Rashid et al., 2008) and evaluated under field conditions (Bashir et al., 2005; Mahmood-ur-Rahman et al., 2007; Bakhsh et al., 2009) in Pakistan. Transgenic plants showed great morphological variations and were different in phenotype as compared to control plants (Bashir et al., 2004, 2005; Mahmood-ur-Rahman et al., 2007).

Bhattacharrya et al., (1994) observed the variability in transgenic tobacco plants having alien genes at different locations of the genome. These variations may be due to different positions of transgene, so it is important to study the position of the transgenes on chromosomes in order to answer the causes of these variations. In the present work, easy, direct and simple procedure was designed to study the integration of $B t$ gene $($ cry $1 A c)$ in transgenic rice and cotton by Fluorescence in situ Hybridization (FISH) and its position was determined.

\section{Materials and Methods}

\section{Plant material and experimental design}

The seeds of Oryza sativa L. variety Basmati-370 were obtained from Rice Research Institute (RRI), Kala Shah Kaku, Lahore, Pakistan. The plants were transformed with cry1Ac, cry2A and cy1Ac and cry $2 A$. Three different plasmids containing $\mathrm{Bt}$ genes were used in these studies as previously described (Bashir et al., 2004, 2005; Riaz et al., 2006; Mahmood-ur-Rahman et al., 2007). The transformation was done through particle bombardment method as described previously (Husnain et al., 1995, 1997; Riaz et al., 2006). Transgenic plants were sown under field conditions according to randomized complete block design (RCBD) with four replications as described by Mahmood-ur-Rahman et al., (2007) following the biosafety guidelines (NBC, 1999).

\section{Polymerase Chain Reaction (PCR)}

DNA from transgenic and Control plants was isolated as described by Dellaporta et al., (1983) and PCR analysis was carried out by using specific primers (Forward primer: 5'ACAGAAGACCCTTCAATATC-3' and Reverse primer: 5'GTTACCGAGTGAAGATGTAA-3') for cry $1 A c$ gene under the following PCR conditions: $95^{\circ} \mathrm{C}$ for 4 minutes, $52^{\circ} \mathrm{C}$ for 1 minute and $72^{\circ} \mathrm{C}$ for 1 minute (one cycle) followed by $95^{\circ} \mathrm{C}$ for 1 minute, $52^{\circ} \mathrm{C}$ for 1 minute and $72^{\circ} \mathrm{C}$ for 1 minute $(30$ cycles) in Thermal Cycler (Model MJ Research, PTC100). DNA extracted from nontransgenic plants was used as negative control while plasmid DNA carrying cry1Ac gene was used as positive control.

\section{Probe Preparation}

PCR product was run on $1 \%$ agarose gel, DNA bands were cut under UV light and eluted by using DNA Extraction Kit (Fermentas K0513) following standard protocol given by manufacturer. The eluted PCR product was labeled by Fluorescien ULS ${ }^{\circledR}$ Labeling Kit (Fermentas K0641) according to the instructions provided by the manufacturer.

\section{Chromosome Preparation}

Growing root tips were collected (1-2 $\mathrm{cm}$ long) and washed in distilled water. They were fixed in fixative (3 vols. Ethanol and 1 vol. Glaciel Acetic Acid) for at least overnight. Fixative was removed and roots were again washed in distilled water. Meristematic portion of roots was cut (1-2 $\mathrm{mm})$ and incubated in enzyme solution: $2 \%$ Pectolyase (Sigma cat\# P 3026) and 3\% Cellulase (Sigma cat\# C 
1184 ) at $37^{\circ} \mathrm{C}$ for $60-90$ minutes for rice and 4-5 hours for cotton roots followed by washing gently with distilled water. Chromosomes were spread on microscopic glass slide with a drop of fixative and airdried. Slides were observed under phase contrast microscope (Carl Zeiss AXIO $100)$ and selected for FISH. The slides were dehydrated in $70 \%, 95 \%$ and $100 \%$ ethanol for 5 minutes in each solution respectively and stored at room temperature.

\section{RNase Treatment}

$1 \%$ RNase A solution was diluted 100 times $(10 \mu 1$ of $1 \%$ RNase A, $10 \mu 11 \mathrm{M}$ Tris $\mathrm{HCl} \mathrm{pH} \mathrm{8.0,5 \mu l} \mathrm{15mM} \mathrm{NaCl} \mathrm{and} 925 \mu 1$ $\mathrm{dH}_{2} \mathrm{O}$ ). $100 \mu \mathrm{l}$ of RNase was added to each slide, covered with cover slip and incubated in wet chamber for 45-60 minutes at $37^{\circ} \mathrm{C}$. The slides were washed in $2 \mathrm{X} \mathrm{SSC}$ at room temperature followed by dehydration in $70 \%, 95 \%$ and $100 \%$ ethanol respectively.

\section{In situ Hybridization}

Hybridization solution $(60 \% \mathrm{dFA}$, 20X SSC, 50\% Dextran Sulphate, 10 $\mu \mathrm{g}$ carrier DNA, 20-30ng probe DNA) denatured at $80-90^{\circ} \mathrm{C}$ for 10 minutes followed by quick chilling on ice. Then, $35 \mu 1$ of it was added to each slide, covered with cover slip and air dried. The chromosomes were denatured at $80^{\circ} \mathrm{C}$ for $10 \mathrm{~min}$ in water bath in $2 \mathrm{X} \mathrm{SSC}$. The slides were incubated at $37^{\circ} \mathrm{C}$ for 18 hours in wet chamber. Next day, the slides were washed with $2 \mathrm{X} \mathrm{SSC}$ at $42^{\circ} \mathrm{C}$ and then with $4 \mathrm{X}$ SSC at $42^{\circ} \mathrm{C}$.

\section{Counterstaining with Propidium Iodide (PI)}

Propidium iodide $(1 \mathrm{mg} / \mathrm{ml})$ was diluted 2000 times on ice by adding $1.0 \mu 1$ PI and $1999 \mu 11 \mathrm{X}$ PBS $(10 \mathrm{X}=1.3 \mathrm{M} \mathrm{NaCl}$; $70 \mathrm{mM} \mathrm{Na} \mathrm{HPO}_{4} ; 30 \mathrm{mM} \mathrm{NaH} \mathrm{PO}_{4} ; \mathrm{pH}$ 7.4). It was added $(500 \mu 1)$ on each slide and incubated for 5 minutes at room temperature. Then slides were washed with
$3 \mathrm{ml}$ of $1 \mathrm{X}$ PBS, covered with cover slip and stored at dark at $4^{\circ} \mathrm{C}$.

\section{Fluorescent Signal Detection}

The fluorescent signals were detected by Fluorescent microscope (Carl Zeiss AXIO 100) using appropriate filter set. The picture of fluorescence signal was taken by CCD camera attached with microscope and analyzed by using software Genus 3.7 provided by Cytovision Applied Imaging Systems. The karyotyping was done using the same software package and the position of the $B t$ gene was determined.

\section{Results}

The transgenic lines were confirmed through PCR for the integration of transgene. The $\mathrm{Bt}$ gene cry1Ac was amplified in rice (Figure 1) and cotton (Figure 2). The amplification of the 565bp fragment of $\mathrm{Bt}$ gene indicated the successful transformation of alien gene into the host genome of rice (Oryza sativa L.) and cotton (Gossypium hirsutum L).

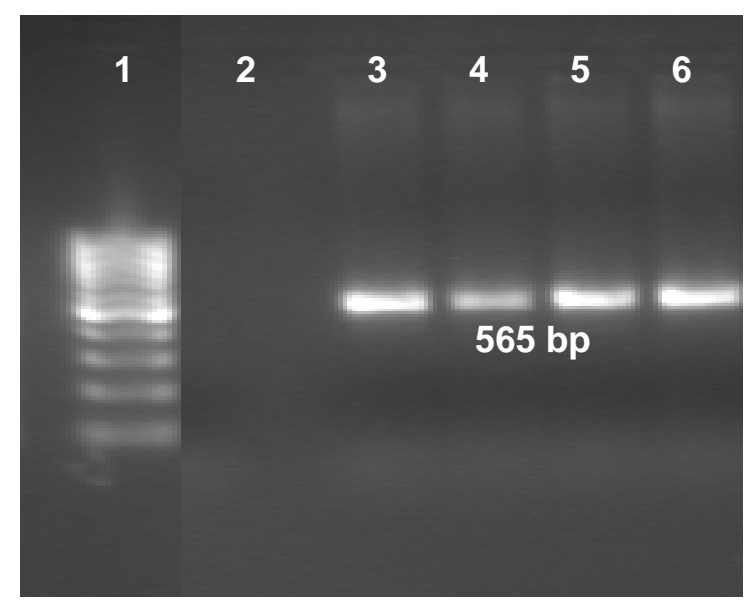

Figure 1. Polymerase Chain Reaction (PCR) of Transgenic and Control Plants of rice revealing the integration of $B t$ gene. Lane 1: 100 bp DNA Ladder Marker, Lane 2: Negative Control (Basmati-370), Lane 3-5: Transgenic rice samples \& Lane 6: Positive Control (Plasmid DNA). 


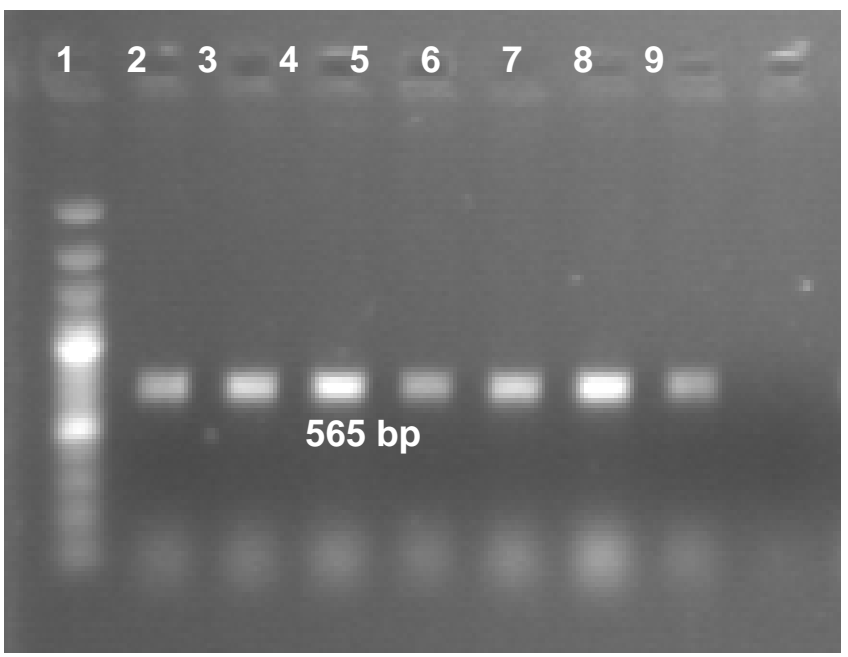

Figure 2. Polymerase Chain Reaction (PCR) of Transgenic and Control Plants of cotton revealing the integration of Bt gene. Lane 1: 100 bp DNA Ladder Marker, Lane 2-7: Transgenic cotton samples, Lane 8: Positive Control (Plasmid DNA) \& Lane 9: Negative Control (CIM-482).

Metaphase chromosomes of PCR genome has 52 chromosomes $(2 n=52)$ positive plants were prepared. The rice (Figure 3b). The selected slides of mitotic diploid genome has 24 chromosomes chromosomes were subjected to FISH $(2 \mathrm{n}=24)$ (Figure $3 \mathrm{a})$ while cotton diploid analysis.

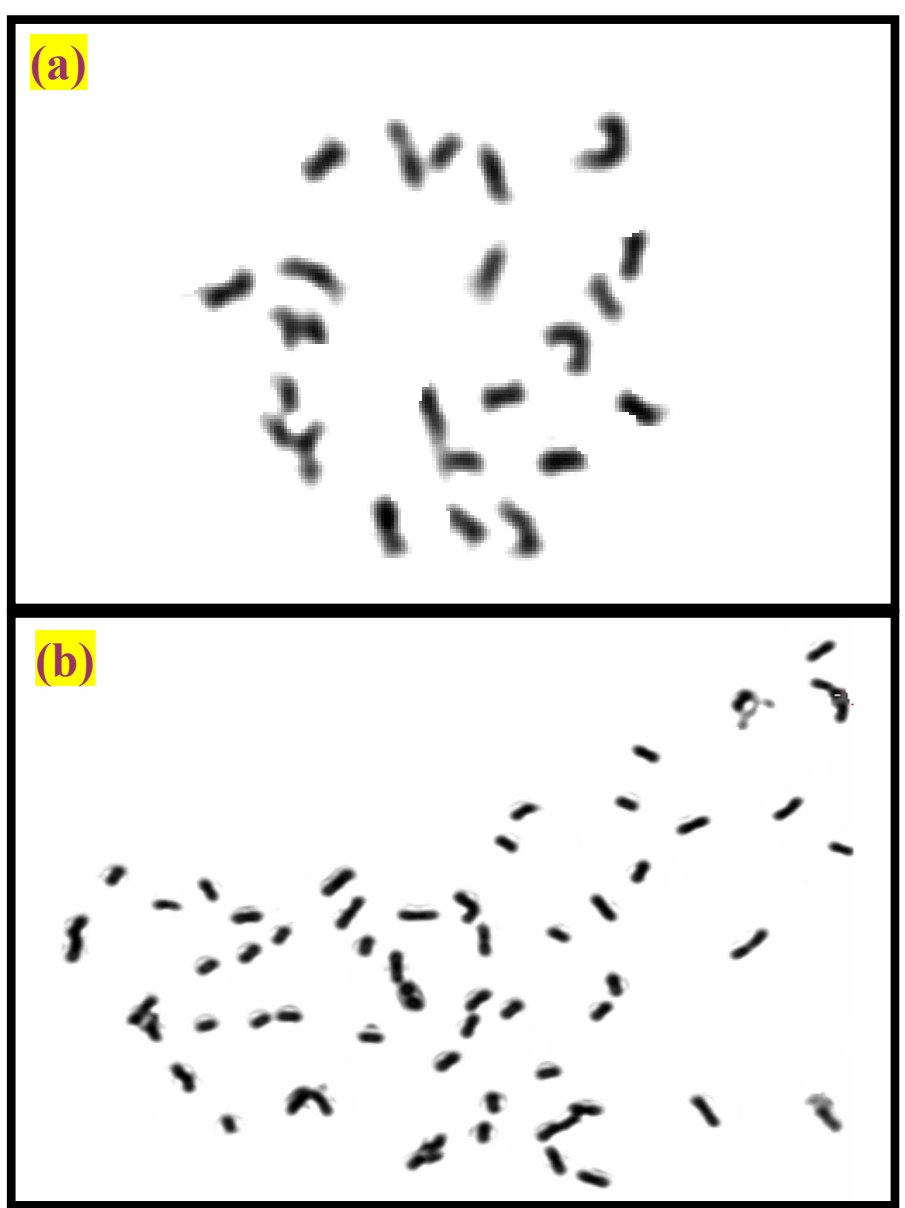

Figure 3. Metaphase chromosome spread of transgenic (a) rice and (b) cotton. 
Fluorescence in situ hybridization (FISH) was carried out for selected lines of transgenic plants. The single color FISH procedure was adopted, the signals of $B t$ gene were in yellow the chromosomes were counterstained with red (Propidium iodide). The transgenic rice was homozygous for $\mathrm{Bt}$ gene having two copies. The transgenic rice showed stable integration of transgene on homologous chromosome number 4 (Figure $4 \mathrm{a}, \mathrm{b}$ ). In cotton, three copies of the $\mathrm{Bt}$ gene were found. On chromosome 4, one copy was present while on chromosome 18 two copies were detected (Figure 5a,b). The karyotypeing of transgenic plants made this protocol easy to determine the location of $B t$ gene on chromosome.
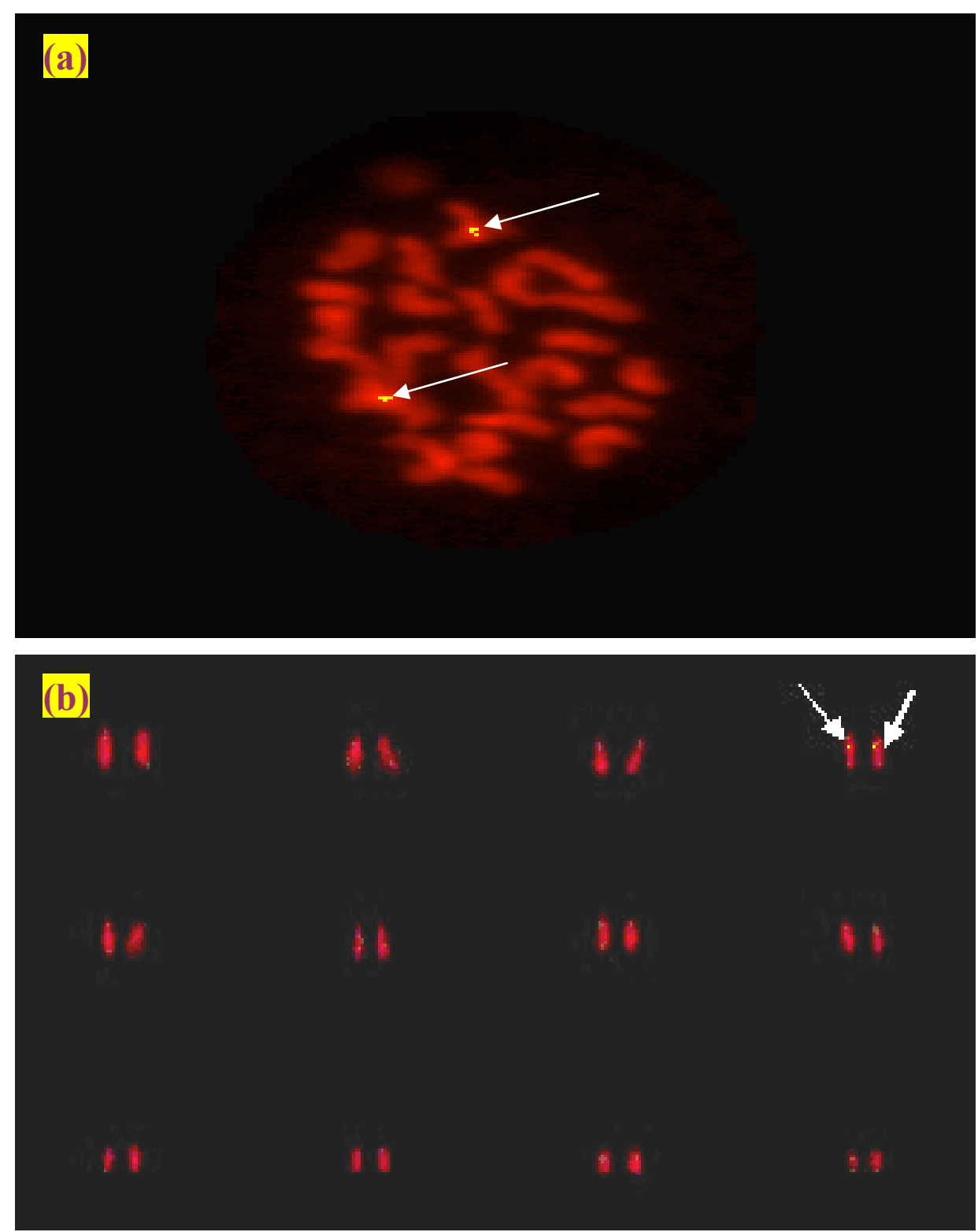

Figure 4. Fluorescence in situ hybridization (FISH) analysis of Bt gene in rice. (A): FISH showing $B t$ gene signals on transgenic rice mitotic chromosomes. (B): Karyotype analysis of transgenic rice showing position of the $B t$ gene on mitotic chromosome. 

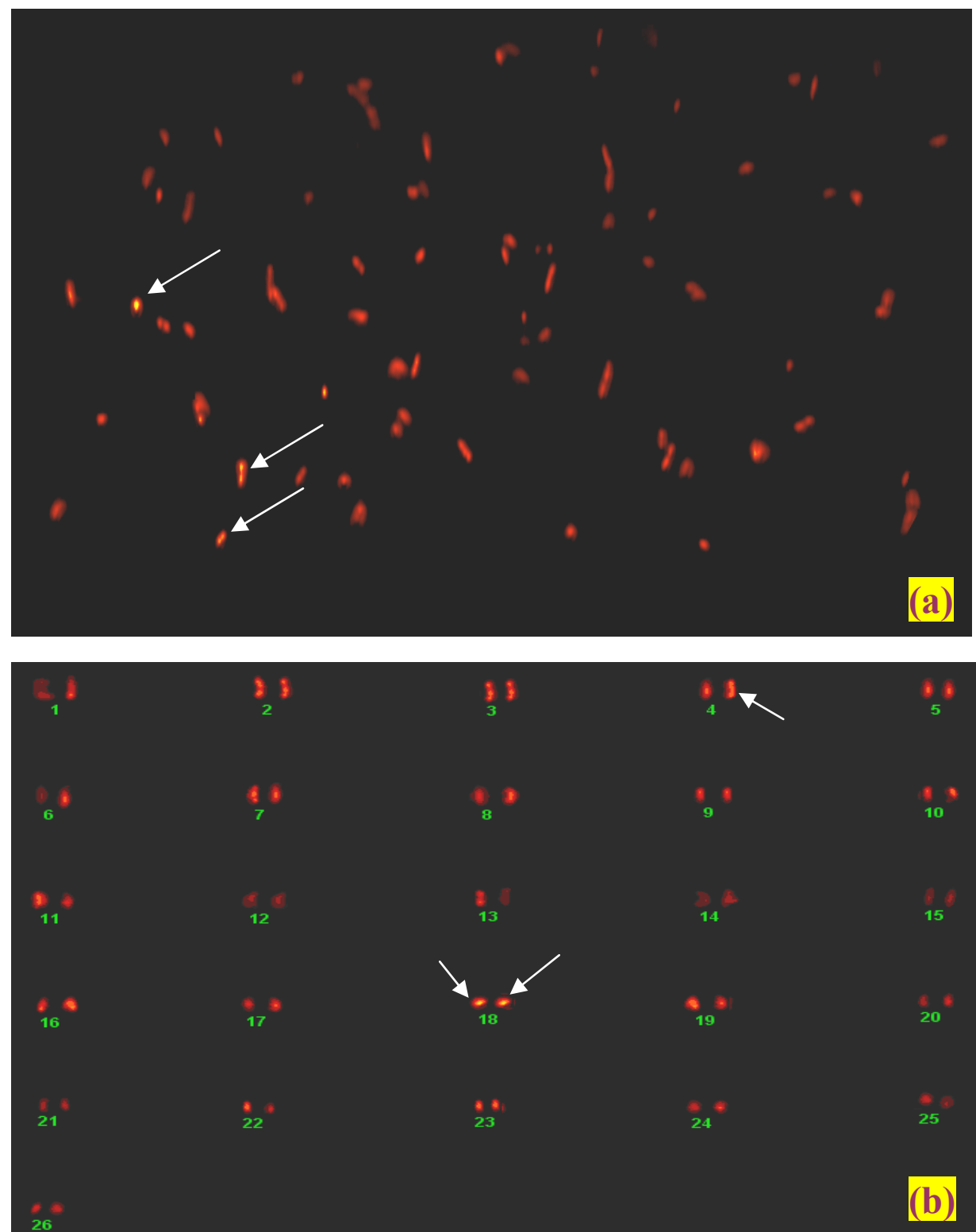

Figure 5. Fluorescence in situ hybridization (FISH) analysis of Bt gene in cotton. (A): FISH showing $B t$ gene signals on transgenic cotton mitotic chromosomes. (B): Karyotype analysis of transgenic cotton showing position of the Bt gene on mitotic chromosome.

\section{Discussion}

Alien genes in transgenic plants when transferred by any suitable procedure always result in partial integration and rearrangements (Jakowitsch et al., 1999). Their site of insertion is more important for a researcher to study the "position effect" of the alien gene in transgenic plant. Many scientists observed phenotypic variations in transgenic plants (Sachuh et al., 1993; Bao et al., 1996; Jiang et al.,
2000; Shu et al., 2002; Bashir et al., 2005; Mahmood-ur-Rahman et al., 2007). Possible reasons for these phenotypic variations may be somaclonal variation (Larkin and Scowcroft, 1981), breakdown of plant genes caused by transgene insertion or insertion mutagenesis (Van et al., 1991), pleiotropy or transgene induced endogenous silencing (Matzke et al., 2000), and position effect (Bhattacharyya et al., 1994) of transgene. In this study the 
integration sites of transgene were directly identified in rice and cotton in rapid and efficient way as compared to available protocols (Fukui et al., 1987; Jiang et al., 1995; Jin et al., 2002). We used fluorescein labeled probes instead of DIGlabeled or that of other methods available. It is direct, fast and efficient procedure of detection and lengthy methods for detection may be avoided. So, we report it as a fast method as compared to already published ones.

Copies of $\mathrm{Bt}$ genes were found interspersed in different regions of chromosomes or on different chromosomes. The results were consistent with those of other researchers, whose genetic mapping has indicated that the insertion sites are widely dispersed in plant chromosomes (Deroles et al., 1988; Heberle-Baors et al., 1988). As reported previously, the frequency of homologous recombination also showed similar variation to that of reported for integration of alien genes from centromeres to chromosome ends. This indicates that the process of alien gene integration resembles that of homologous recombination, even though transgene may be non-homologous to genomic DNA. Therefore, it could be concluded that transgene recognition sites occur all along chromosomes causing variations in morphology of plants.

\section{Acknowledgements}

The authors gratefully acknowledge the financial support from the Higher Education Commission, Government of Pakistan. The authors are also thankful to Dr. Fida Muhammad Abbasi, Senior Scientific Officer, National Agriculture Research Centre, Islamabad, Pakistan for his valuable suggestions and critical evaluation of the protocol.

\section{References}

Bajaj, S. and A. Mohanty. 2005. Recent advances in rice biotechnology: towards genetically superior transgenic rice. Plant Biotechnol. J. 3:275-307.

Bakhsh, A., A. Q. Rao, A. A. Shahid, T. Husnain and S. Riazuddin. 2009. Insect resistance and risk assessment studies in advance lines of $\mathrm{Bt}$ cotton harboring cry1Ac and cry $2 \mathrm{~A}$ genes. Amer. Eur. J. Agric. Environ. Sci. 6(1):1-11.

Bao, P. H., S. Granata, S. Castiglione, G. Wang, C. Giordani, E. Cuzzoni, G. Damiani, C. Bandi, S. K. Datta, K. Datta, I. Portrykus, A. Callegarin and F. Sala. 1996. Evidence for genomic changes in transgenic rice (Oryza sativa L.) from protoplast. Transgenic Res. 5:97-103.

Bashir, K., T. Husnain, T. Fatima, Z. Latif, S. A. Mehdi and S. Riazuddin. 2004. Field evaluation and risk assessment of transgenic indica basmati rice. Mol. Breed. 13:301-312.

Bashir, K., T. Husnain, T. Fatima, N. Riaz, R. Makhdoom and S. Riazuddin. 2005. Novel indica Basmati line (B370) expressing two unrelated genes of Bacillus Thuringiensis is highly resistant to two lepidopteran insects in the field. Crop Prot. 24:870-879.

Bhattacharyya, M. K., B. A. Stermer and R. A. Dixon. 1994. Reduced variation in transgene expression from a binary vector with selectable markers at the right and left T-DNA borders. Plant J. 6(6):957-968.

Dellaporta, S. L., J. Wood and J. B. Hicks. 1983. SA plant DNA minipreparation: Version II. Plant Mol. Biol. Rep. 1:19-21.

Deroles, S. C. and R. C. Gardner. 1988. Analysis of the T-DNA structure in a 
large number of transgenic petunias generated by Agrobacteriummediated transformation. Plant Mol. Biol. 11:365-377.

Fukui, K., K. Kakeda, J. Hashimoto and S. Matsuoka. 1987. In situ hybridization of ${ }^{125}$ I-labeled rRNA to rice chromosomes. Rice Gen. News. 4:114-116.

Heberle-Baors, E., B. Charvat, D. Thompson, J. P. Schernthaner, A. Barta, A. J. M. Matzke and M. A. Matzke. 1988. Genetic analysis of TDNA insertions into the tobacco genome. Plant Cell Rep. 7:571-574.

Husnain, T., F. Khanum, S. Riazuddin and M. P. Gordon. 1995. Transformation of Basmati rice (Oryza sativa L.) with bacterial genes by particle bombardment. Pak. J. Plant Sci. 1(2):219-228.

Husnain, T., T. Malik, S. Riazuddin, M. P. Gordon. 1997. Studies on the expression of marker genes in chickpea. Plant Cell Tissue Organ Cult. 49:7-16.

Jakowitsch, J., I. Papp, E. A. Moscone, J. van der Wunden, M. Matzke and A. J. M. Matzke. 1999. Molecular and cytogenetic characterization of a transgene locus that induces silencing and methylation of homologous promoters. Plant J. 17:131-140.

Jiang, J., B. S. Gill, G. L. Wang, P. C. Ronald and D. C. Ward. 1995. Metaphase and interphase fluorescence in-situ hybridization mapping of the rice genome with bacterial artificial chromosomes. Proc Nat. Acad. Sci. USA 92:4487-4491.

Jiang, J., S. D. Linscombe, J. Wang and J. H. Oard. 2000. Field evaluation of transgenic rice (Oryza sativa L.) produced by agrobacterium and particle bombardment methods. In: Plant and Animal Genome VIII Conference (January 9-12，2000, Town and County Hotel, San Diego, CA) (Abstr).

Jin, W., Z. Li, Q. Fang, I. Altosaar, L. Liu and Y. Songm. 2002. Flourescence in situ hybridization analysis of alien genes in Agrobacterium-mediated cry1A(b)-transformed rice. Annal. Bot. 90:31-36.

Larkin, P. J. and W. R. Scowcroft. 1981. Somaclonal variation- A novel source of variability from cell culture from plant improvement. Theor. Appl. Genet. 60:197-214.

National Biosafety Committee (NBC). 1999. Biosafety guidelines in genetic engineering and biotechnology. Ministry of Environment Local Government, Rural Development, Government of Pakistan.

Mahmood-ur-Rahman, H. Rashid, A. A. Shahid, K. Bashir, T. Husnain and S. Riazuddin. 2007. Insect resistance and risk assessment studies of advanced generations of Basmati rice expressing two genes of Bacillus thuringiensis. Elect. J. Biotechnol. 10(2):241-251.

Majeed, A., T. Husnain and S. Riazuddin. 2000. Transformation of Virus Resistant Genotype of Gossypium hirsutum L., with Pesticidal Gene. Plant Biotechnol. 17(2):105-110.

Matzke, M. A., M. F. Mette and A. J. M. Matzke. 2000. Transgene silencing by the host genome defense: implications for the evolution of epigenetic control mechanism in plants and vertebrates. Plant Mol. Biol. 43:401-415. 
Rashid, B., S. Zafar, T. Husnain and S. Riazuddin. 2008. Transformation and inheritance of $\mathrm{Bt}$ genes in Gossypium hirsutum. J. Plant Biol. 51(4):248254.

Riaz, N., T. Husnain, T. Fatima, R. Makhdoom, K. Bashir, L. Masson, I. Altosaar and S. Riazuddin. 2006. Development of Indica Basmati rice harboring two insecticidal genes for sustainable resistance against lepidopteran insects. S. Afr. J. Bot. 72:217-223.

Sachuh, W., M. R. Nelson, D. M. Bigelow, T. V. Orum, C. E. Orthj, P. T. Lynch, P. S. Eyles, N. W. Blackhay, J. Jones, E. C. Cocking and M. R. Davey. 1993. The phenotypic characterization of $\mathrm{R}_{2}$ generation transgenic rice plants under field conditions. Plant Sci. 89:69-79.
Shu, G. Y., H. Cui, G. Ye, D. Wu, Y. Xia, M. Gao and I. Altosaar. 2002. Agronomic and morphological characterization of Agrobacteriumtransformed $B t$ rice plants. Euphytica 127:345-352.

Van, L. M., R. Vanderhaeghen and M. M. Van. 1991. Insertional mutagenesis in Arabidopsis thaliana Isolation of a TDNA-linked mutation that alters leaf morphology. Theor. Appl. Genet. 81:277-284. 